\title{
Jeremy Waldron and the Circumstances of Politics
}

\section{Alexander Latham-Gambi}

Abstract: This article examines Jeremy Waldron's concept of the 'circumstances of politics' (CoP), which he describes as the felt need for a common decision in the face of disagreement. Waldron uses the CoP to detach certain issues surrounding civic virtue and institutional design from questions about substantive principles like justice, human rights etc.. While emphasis is often placed on the fact of disagreement, I argue that the other aspect of the CoP, the need for collective action, is in fact the more fundamental. Waldron's arguments rely on an understanding that there is expressive value in citizens affirming commitment to the political community and on an awareness of how the nature of politics as public collective action is structured by the constitutional architecture. I argue that a lopsided focus on disagreement threatens to obscure the fact the political sphere is itself a fragile achievement that is in need of continual support.

Jeremy Waldron has argued that contemporary political philosophy fails to take adequate account of what he calls the 'circumstances of politics' (CoP). The CoP consists of two facts which characterize modern societies, namely (i) that citizens experience 'the felt need... for a common framework or decision or course of action', notwithstanding (ii) the prevalence of 'disagreement about what that framework, decision, or action should be'. ${ }^{1}$ Waldron's claim is more significant

\footnotetext{
Alexander Latham-Gambi is a Lecturer in the Hillary Rodham Clinton School of Law at Swansea University, Richard Price Building, Singleton Park, Swansea, UK, SA2 8PP (a.g.latham@swansea.ac.uk).

This paper has benefitted from insightful comments from audiences at the Edinburgh Constitutional Law Discussion Group and the workshop on 'Constitutionalism and Disagreement' at the XXIX IVR World
} 
than it might appear at first glance. He has not merely pointed to a failure of political philosophy to address this kind of disagreement, as one might lament a lack of attention to environmental issues or the rights of non-human animals. Nor is he simply making the empirical claim that one cannot expect disagreement to disappear. He is making a claim about the nature of politics itself. 'The prospect of persisting disagreement', he says, is 'one of the elementary conditions of modern politics', such that '[n]othing we can say about politics makes much sense if we proceed without taking this condition into account. ${ }^{2}$

Waldron has referred to the $\mathrm{CoP}$ in a variety of arguments, ${ }^{3}$ which have given rise to lively debates, ${ }^{4}$ yet little attention has been paid to his more general claim. A partial exception is perhaps to be found in the 'political realist' school, some of whom have looked to enlist the CoP for their

Congress at the University of Lucerne, and I am grateful to the Society of Legal Scholars for providing the funding that enabled me to attend the latter event. I would especially like to thank Elizabeth Craig, Dimitrios Kyritsis, Bal Sokhi-Bulley, Felipe Oliveira de Sousa, Lindsay Stirton and three anonymous reviewers for thoughtful written feedback.

${ }^{1}$ Jeremy Waldron, Law and Disagreement (Oxford: Oxford University Press, 1999), 102.

${ }^{2}$ Jeremy Waldron, The Dignity of Legislation (Cambridge: Cambridge University Press, 1999), 154.

${ }^{3}$ Many of these arguments are collected in Waldron, The Dignity of Legislation; Waldron, Law and Disagreement; and Jeremy Waldron, Political Political Theory: essays on institutions (Cambridge: Harvard University Press, 2016).

${ }^{4}$ The literature is vast, here I can only cite a selection: Christopher L. Eisgruber, "Democracy and Disagreement: a comment on Jeremy Waldron's Law and Disagreement," New York University Journal of Legislation and Public Policy 6, no. 1 (Fall 2002); Larry Kramer, The People Themselves: popular constitutionalism and judicial review (Oxford: Oxford University Press, 2004), chap 9; Dimitrios Kyritsis, "Representation and Waldron's Objection to Judicial Review," Oxford Journal of Legal Studies 26, no. 4 (Winter 2006); David M. Estlund, Democratic Authority: a philosophical framework (Princeton: Princeton University Press, 2008), chap 5; Andrew Mason, "Rawlsian Theory and the Circumstances of Politics," Political Theory 38, no. 5 (October 2010); W. Bradley Wendel, Lawyers And Fidelity To Law (Princeton: Princeton University Press, 2010), chap 3; Ronald Dworkin, Justice For Hedgehogs (London: Harvard University Press, 2011), chap 18. 
cause, ${ }^{5}$ yet approval for Waldron's idea has not yet been accompanied by close analysis of his arguments. I find this omission curious, since, if the twin facts of the CoP are indeed 'the elementary conditions of modern politics', then this represents an important philosophical discovery. This article looks to remedy this gap, directing critical attention squarely on the CoP. In particular, while discussion of the CoP in the literature has concentrated on the fact of disagreement (as, at times, has Waldron himself), I shall argue that the other fact, the felt need for a common course of action, is actually the more fundamental. This has an important consequence: lopsided focus on disagreement might suggest a thin, instrumental conception of politics, whereas appreciation of the significance of collective action points us towards a richer understanding of what politics is, why it is valuable and how it might be protected.

I start (I) by setting out the basic role of the CoP, which is to draw a distinction between 'substantive' political values (like justice and human rights) and those values that are the subjectmatter of Waldron's 'political political theory' (such as civility, loyal opposition and the rule of law) on the other. The crucial claim is, I suggest, that the challenge of enabling citizens to view themselves as members of a self-governing political community requires substantive views to be set to one side when considering issues concerning political disagreement. I then (II) examine a question that Waldron neglects: what does it mean for a disagreement to be political? My answer is that political disagreements are inherently public, that is, they are disagreements about what actions should be taken collectively in relation to public affairs, and are widely understood as such.

\footnotetext{
5 See William Galston, "Realism in Political Theory," European Journal of Political Theory 9, no. 4 (October 2010): 391; Matt Sleat, Liberal Realism: a realist theory of liberal politics (Manchester: Manchester University Press, 2013), 45; and Richard Bellamy, "Turtles all the way down? Is the political constitutionalist appeal to disagreement self-defeating? A reply to Cormac Mac Amhlaigh" International Journal of Constitutional Law 14, no. 1 (January 2016): 207. Waldron has disassociated himself from the realist movement: see Waldron, Political Political Theory, 5.
} 
The very capacity to conceive of conflicts in political terms requires a shared understanding of 'publicness', and is thus a significant achievement. This must be borne in mind when thinking about institutional design, since political institutions are not simply decision-making mechanisms: they play a crucial role in shaping the way in which citizens understand the political sphere, and the political community.

I then look in more detail at some of the particular uses that Waldron makes of the CoP, focusing on the authority of law (III), civility and loyal opposition (IV), the so-called 'dignity' of legislation (V) and judicial review (VI). I argue that Waldron relies on two important ideas: firstly, that there is expressive value in affirming a commitment to the political community; and secondly, that the nature of politics as public collective action is structured by the constitutional architecture. These ideas are, however, overlooked in his 'core case' against judicial review, resulting in a disappointingly thin line of reasoning (grounded on a majoritarian conception of democracy), which fails to do justice to the insights he presents elsewhere.

I conclude (VII) by suggesting that a fuller understanding would see the CoP not merely as a predicament to be managed, but as the defining characteristics of the political condition, and, as such, something worthy of protection. This is particularly pertinent at a time in which the political condition finds itself under threat from two directions, challenged by neoliberalism on one side and populism on the other. We must recognize the potential of the expressive value of political virtues, practices and institutions to buttress and perhaps even rejuvenate the shared sense that certain matters are of common concern and are the fitting subject of public contestation and debate.

\section{The Basic Role of the Circumstances of Politics}


The basic role of the $\mathrm{CoP}$ is to detach certain political issues, particularly those concerning constitutional design and civic obligation, from substantive questions of political morality (justice, human rights, etc.). The CoP tells us that, when determining how a political constitution ought to be structured, or the duties citizens owe one another, we should bracket our substantive political views and seek to exercise the 'distinctively political virtues' ${ }^{6}$ The idea is not that a highly-attuned sense of civic virtue or well-designed constitution will cause our substantive disagreements to dissolve, but that bracketing those disagreements will allow the polity to be understood as a project of collective self-government notwithstanding the persistence of political division.

Waldron draws an analogy with the well-known idea of the 'circumstances of justice', a set of facts which certain philosophers have argued must be presupposed by any theory of justice. ${ }^{7}$ A typical list would include vulnerability; moderate scarcity of resources; plurality of conceptions of the good; shortcomings of knowledge; and mutual disinterest or limited altruism. Absent these conditions, the argument goes, justice would be neither necessary nor possible (if resources were unlimited, the idea of a fair distribution would be meaningless). Theorists who adopt this idea believe that, whatever idealizations a conception of justice might employ, it cannot abstract away from these circumstances. Waldron makes a parallel claim for the CoP: 'whatever else we wish away in political philosophy, we should not wish away the fact that we find ourselves living and

\footnotetext{
${ }^{6}$ See note 13.

${ }^{7}$ See David Hume, A Treatise of Human Nature (Oxford: Oxford University Press, 2000), 3.2.2; David Hume, "An Enquiry Concerning the Principles of Morals," in Enquiries Concerning Human Understanding and Concerning the Principles Of Morals (Oxford: Clarendon Press, 1975), section iii; John Rawls, A Theory Of Justice (Oxford: Clarendon Press, 1973), §22.
} 
acting alongside many with whom there is little prospect of our sharing a view about justice, rights or political morality'. ${ }^{8}$

The circumstances of justice delineates the scope of justice, within which other virtues may have to be set to one side. For example, Hume uses the circumstances of justice to distinguish the 'artificial' virtue of justice from the 'natural' virtue of benevolence. ${ }^{9}$ The natural concern that people have for others, he claims, is too weak a sentiment to be able to undergird the kind of mutual trust required to maintain a large-scale society. The fact of limited altruism directs us to abandon hope of establishing a polity (or political community - I use these terms synonymously) in which citizens bear the kind of regard towards one another that they hold towards friends and family. The inclusion of limited altruism in Hume's circumstances of justice thus establishes that, within its proper scope, justice requires us to set benevolent feelings to one side. In Rawls' account reasonable pluralism and mutual disinterest play a similar role. For Rawls, acceptance of these facts demands that principles of justice be 'freestanding' from the general conceptions of morality that individuals accept in their personal lives. ${ }^{10}$ So despite the enormous differences between their theories, both Hume and Rawls use the circumstances of justice to stipulate that certain kinds of considerations should be set aside when determining principles by which society as a whole is to be governed.

\footnotetext{
${ }^{8}$ Waldron, The Dignity of Legislation, 154.

${ }^{9}$ Hume, Treatise, 3.2.2.

${ }^{10}$ Rawls, Theory of Justice, §22; John Rawls, Justice as Fairness: a restatement (Cambridge: Belknap Press, 2001), §24; and John Rawls, Political Liberalism (New York: Columbia University Press, 1993), Lecture I, §2.
} 
Waldron's CoP take this thought a step further. Distinguishing between '(i) theorizing about justice (and rights and the common good etc.), and (ii) theorizing about politics', ${ }^{11}$ Waldron argues that we should set aside our views about the former when engaging in the latter. By 'theorizing about politics' he means what he has labelled 'political political theory': theory that examines 'the way our political institutions house and frame our disagreements about social ideals and orchestrate what is done about whatever aims we can settle on'. ${ }^{12}$ Such issues engage 'the distinctively political virtues, such as civility, the toleration of dissent, the practice of loyal opposition, and... the rule of law'. ${ }^{13}$ Just as the circumstances of justice direct us to set considerations of benevolence and personal morality aside when determining what justice requires, so the CoP demand that we set substantive views about justice, rights, etc. to one side when considering matters concerning political institutions, political authority and our treatment of our political opponents. ${ }^{14}$

The most straightforward illustration of this argument comes in Waldron's critique of 'rights instrumentalism' - the view that, when choosing a decision-making procedure, we should select whichever is most likely to reach the correct decision. ${ }^{15}$ Charles Beitz had claimed that the argument from political equality to majority voting rests on 'an implausibly narrow understanding

\footnotetext{
${ }^{11}$ Waldron, Law and Disagreement, 3.

12 Jeremy Waldron, "Political Political Theory," in Political Political Theory, 6.

${ }^{13}$ Waldron, Law and Disagreement, 102.

${ }^{14}$ This is not to say that substantive views about justice (etc.) are irrelevant in political political theory. People who hold certain theories of justice (particularly non-liberal theories) might be led to reject ideals such as civility, toleration and so on, and will thus not accept that they ought to bracket their substantive conception of justice when considering constitutional issues. This is directly parallel to Rawls' claim that those who hold 'unreasonable' comprehensive doctrines will be unable to accept a political conception of justice (see Rawls, Political Liberalism, Lecture II, §3).

${ }^{15}$ Waldron, Law and Disagreement, 252-4.
} 
of the more basic principle, from which substantive concerns... have been excluded' ${ }^{16}$ Waldron's response is that, while there is a sense in which equal respect for persons requires sensitivity to substantive outputs, 'this broad notion of respect is unusable in society's name in the circumstances of politics ${ }^{,}{ }^{17}$ We need a decision-procedure precisely because we disagree about what counts as a respectful outcome, and so anything that refers us back to the issue of substance 'would reproduce not resolve the decision-problem in front of us'. ${ }^{18}$ Rights-instrumentalism is 'question-begging'; it 'presupposes our possession of the truth about rights in designing an authoritative procedure whose point it is to settle that very issue'. ${ }^{19}$ In order to avoid begging the question, we have to bracket substantive views about rights when deciding how such rights are to be determined.

While Waldon does not state this explicitly, I suggest that the point of such bracketing is to allow all citizens to view themselves as members of a self-governing polity. Designing the decision-making process so as to privilege a particular conception of rights would effectively preclude those who hold different views from being full participants in that process. ${ }^{20}$ The process would appear rigged against them from the outset. It is only if we set substantive questions aside when selecting decision-making procedures that we will enable decision-making to be seen as the collective action of the political community as a whole, notwithstanding their differences in opinion.

\footnotetext{
${ }^{16}$ Charles R. Beitz, Political Equality: an essay in democratic theory (Princeton: Princeton University Press, 1989), 64.

${ }^{17}$ Waldron, Law and Disagreement, 116 (emphasis added).

${ }^{18}$ Ibid., 117.

${ }^{19}$ Ibid., 253.

${ }^{20}$ See ibid., 159-61. See also J. Habermas, "Reconciliation Through the Public Use of Reason: Remarks on John Rawls' political liberalism," Journal of Philosophy 92, no. 3 (March 1995), for an argument along similar lines.
} 
This challenge is more demanding than simply creating a fair decision-making process. There is, for example, nothing unfair about a procedure that selects outcomes at random, but random selection is not a process of collective action. And there may well be other decisionmaking processes which are not unfair but which are nevertheless defective in that they do not allow us to understand the political process as a truly collective endeavor.

The basic role of the CoP, then, is to detach certain issues from questions of substantive political morality. Political political theory rests on the belief that a self-governing political community must exercise 'distinctively political virtues' ${ }^{21}$ to deal with political disagreements. To invoke the $\mathrm{CoP}$ is essentially to invoke this idea.

\section{What Makes a Disagreement Political? Publicity, Collective Action and the Constitutional Architecture}

Perhaps surprisingly, Waldron is not explicit about what it means for a disagreement to be political. He states that disagreement in the $\mathrm{CoP}$ is 'among the members of a certain group' concerning 'a common framework, decision or course of action', ${ }^{22}$ and that the group in question must be a 'political body' ${ }^{23}$ and a 'community'. ${ }^{24}$ But he does not really expand on these comments. In this section I examine the question of what makes a disagreement political in nature, laying the groundwork for the analysis of the particular arguments in which Waldron invokes the CoP.

\footnotetext{
${ }^{21}$ See note 13 .

${ }^{22}$ Waldron, Law and Disagreement, 102.

${ }^{23}$ Waldron, The Dignity of Legislation, 154: 'We may say... that disagreement among citizens as to what they should do, as a political body, is one of the circumstances of politics.'

${ }^{24}$ Jeremy Waldron, "Kant's Legal Positivism," Harvard Law Review 109, no. 7 (May 1996): 1538: 'Because we disagree about which position should stand and be enforced in the name of the community, we need a process - a political process - to determine what the position should be.'
} 
The disagreement in the CoP is practical political disagreement. 'Practical' disagreement signifies that the disagreement concerns what ought to be done in a particular situation, in contrast with 'theoretical' political disagreement about principles of political morality or the nature of an ideally just society. ${ }^{25}$ While practical political disagreement on a particular matter will often reflect more abstract theoretical disagreement, the two types of disagreement are distinct. ${ }^{26}$ With theoretical disagreement, the wisest course of action is often to 'agree to disagree', that is, to let the disagreement lie without agreeing upon any common position. Practical disagreements cannot be dealt with in this way: they give rise to the CoP because they give rise to the need for a decision.

We can distinguish between practical disagreement and conflict. Disagreement does not exist simply because different people propose incompatible courses of action. The fact that we each intend to take the last biscuit does not constitute a disagreement. Disagreement entails that we share some normative concept and diverge over its proper application. We only disagree if we each think that we ought to take the last biscuit, have a right to the last biscuit, or something similar. Conflict may arise as a result of clashes of interests in the absence of any disagreement.

Not all practical disagreements are political disagreements: to distinguish the latter, we need a specific account of the distinctive nature of politics. Waldron's statement that the relevant

\footnotetext{
${ }^{25}$ My categorization of disagreements about principles of political morality as 'theoretical' is not as controversial as it might sound. I do not mean to call into question the place of political philosophy within 'practical' as opposed to 'theoretical' philosophy. I mean only that philosophical disagreements about principles of justice and so on are not, in themselves, about which specific actions ought to be carried out in the real world.

${ }^{26}$ Waldron is not always as clear as he might be on this distinction. For example, at one point in Law and Disagreement he announces that: 'In this book I am concerned with disagreements about matters like social policy, social justice, and individual rights', which he refers to later on the same page as 'the disagreements we have in politics (and in political philosophy) concerning the fundamental principles of justice and right' (Waldron, Law and Disagreement, 149). Similar conflation of the kind of disagreement in the CoP with theoretical disagreement about political morality appears at 1,93 and 105.
} 
disagreements are 'among the members of a certain group', and concern 'a common framework, decision or course of action' ${ }^{27}$ is over-inclusive: it would include, say, a disagreement between members of a cricket team about the order in which they should go in to bat. Waldron's various discussions of the CoP lack a detailed account of politics. But a sense of what such an account would include can be gleaned from another passage, where Waldron discusses the political theory of Hannah Arendt:

The central case of an Arendtian zoon politikon is a person who engages seriously and responsibly in public business under the auspices of public institutions. He has the judgment to discern which issues are political and which are merely social or personal. He can see that what matter in politics are interests and purposes that are shared by all as members of a community. ${ }^{28}$

Politics is thus the conduct of 'public business', through 'public institutions'. Political matters are not 'merely social or personal': they are 'shared by all', or more properly, all citizens, by virtue of their status 'as members of a community'.

To develop this, we can say that it is only when members of a group see themselves as a public that the group will be capable of having truly political disagreements. This sense of publicness has three interrelated respects. Firstly, politics concerns affairs which are public as opposed to private: political matters are by their very nature everybody's business (or at least every citizen's business). Secondly, politics are the affairs of the public: political decisions should not be made for the benefit of some individual or group's personal interest (in politics, salus populi suprema lex esto). Thirdly, politics concerns public action: political disagreements are about not

\footnotetext{
${ }^{27}$ Ibid., 102.

${ }^{28}$ Jeremy Waldron, "The Constitutional Politics of Hannah Arendt," in Political Political Theory, 291.
} 
what you or I or anyone else should do as private individuals, but about what we should do as a polity.

Politics thus provides conceptual space for a certain type of disagreement. The notion that certain matters engage a set of distinctively public considerations - what we might call the 'sphere of the political' - provides a common reference point that allows clashes between individuals and groups to emerge as genuine disagreements rather than mere conflicts. It creates a mode of commonality that transcends personal affective bonds and adherence to any shared creed, and allows opposed parties - even those characterized by trenchant and bitter rivalry - to view themselves as arguing about a shared interest to which they are all in principle committed.

We can thus see how the ability to have practical political disagreements can itself be viewed as a significant achievement. Such disagreement can only take place where there exists a political community: a group of people that conceives of itself as having certain public affairs that are to be dealt with collectively. This collective self-conception requires a 'public sphere' - a shared space in which members of society can discuss matters of common concern - and it requires people to come to political debates willing to continue to resolve issues collectively. In turn this relies upon felicitous social conditions and needs to be maintained by an appropriate set of political and social institutions. There is thus a significant disanalogy between the CoP and the circumstances of justice: while the circumstances of justice are simply facts about the world that the theorist of justice must accept, the CoP only holds under demanding conditions which we have good reason to promote and defend. Justice does not demand that the circumstances of justice be preserved, but politics ought to strive to maintain the CoP.

This perspective reveals an important facet of those political institutions that are the subject-matter of political political theory: they embed ideas about the nature of politics and the 
polity into our shared practices. A narrow focus on the practical problems raised by disagreement might tempt one to think of political institutions as simply decision-making mechanisms, taking some set of 'inputs' (political beliefs and preferences) and converting them into 'outputs' (political decisions). Rawls, for example, has said: 'We may think of the political process as a machine which makes social decisions when the views of representatives and their constituents are fed into it. ${ }^{29}$ But political institutions also play a more fundamental role. The institutional structure colors society's sense of the boundaries of the political, be they topical (does politics extend to the regulation of commercial arrangements between consenting adults?), territorial (are 'we' the people of Scotland, of the UK, of Europe?) or what we might call the limits of political possibility (is it feasible to expect politics to effectively govern the conduct of multinational corporations?). The nature of politics - conceived of as a form of public collective action - is structured by the constitutional architecture. ${ }^{30}$ As we shall see, a number of Waldron's arguments rely upon a recognition of the way in which political institutions serve to frame collective political action as such.

To recap: the disagreements in the $\mathrm{CoP}$ are practical political disagreements, which means disagreements about what actions should be taken collectively by a political community in the pursuance of its public affairs. This requires a shared sense of publicness that is maintained in part by the constitutional architecture that helps to shape a political community's understanding of itself. As we shall see below, this 'framing' role of political institutions needs to be borne in mind when considering the merits of competing constitutional systems.

\footnotetext{
${ }^{29}$ Rawls, Theory of Justice, 196.

${ }^{30}$ Waldron discusses this issue directly with reference to the work of Hannah Arendt: see Waldron, "Constitutional Politics," 203-12.
} 


\section{The Authority of Law: Expressive not Instrumental}

One of the most basic arguments in which Waldron refers to the CoP holds that the fact of disagreement provides us with a reason to respect the authority of law. Since disagreement renders collective action a fragile achievement, the argument goes, collective decisions are worthy of respect. ${ }^{31}$ Put this way, legal authority seems to rest fairly straightforwardly on the value of expressing a commitment to the political community's collective self-government. However, Waldron muddies the waters by conflating the status of the law as the product of collective action with the law's capacity to co-ordinate behavior in the face of practical disagreement. ${ }^{32}$

Waldron seems to envisage acceptance of the authority of law as effecting both a shift to a collective point of view and (consequently) the resolution of disagreement. ${ }^{33}$ On this picture, the law consists of shared standards which we agree to accept so as to resolve the problem of disagreement. Law thus takes us from the CoP to shared acceptance of a common position (a situation I shall call 'legal agreement'). Here the resolution of disagreement runs concurrently with the shift from considering the issue on the basis of one's individual opinion about justice to accepting a collectively-determined position. I call this the shift from 'I-thinking' to 'we-

\footnotetext{
${ }^{31}$ See Waldron, "Kant's Legal Positivism"; Waldron, Law and Disagreement, 99-107; Jeremy Waldron "Lex Satis Iusta," Notre Dame L Rev 75, no. 5 (August 2000); and Jeremy Waldron, "Authority for Officials," in Rights, Culture And The Law: themes from the legal and political philosophy of Joseph Raz, ed. Lukas H. Meyer, Stanley L. Paulson and Thomas W. Pogge (Oxford: Oxford University Press, 2003).

${ }^{32}$ See especially Waldron, "Kant's Legal Positivism," 1539-40; and Waldron, Law and Disagreement, 103-5.

${ }^{33}$ By 'resolution' of disagreement I do not mean that the disagreement ceases: when we agree upon a collective binding standard we do not abandon our individual opinions, we merely agree to abide by the collective standard while it remains in force, notwithstanding the persistence of our disagreement.
} 
thinking, ${ }^{34}$ On this way of understanding things, to adopt a collective viewpoint is eo ipso to overcome the problem presented by the fact of disagreement.

Note, however, that the two components of legal agreement - the adoption of a collective viewpoint and the resolution of disagreement - can be separated. Most straightforwardly, we can agree without adopting a collective viewpoint: we might just happen to hold the same view (a situation I call 'political consensus'). More significantly: we can accept a collective viewpoint without resolving our disagreement. The phenomenon of legal disagreement shows this to be the case. It is not at all rare for reasonable citizens to be in possession of all the relevant facts and yet still disagree over what the law requires. So even when we agree to set our personal convictions to one side and take up the collective viewpoint of the law, we still sometimes end up disagreeing about how we ought to proceed.

Recognizing this leads to the more complex picture shown in Table 1:

$\underline{\text { Table } 1}$

\begin{tabular}{|l|l|l|}
\hline & $\begin{array}{l}\text { Column A: } \\
\text { Disagreement }\end{array}$ & $\begin{array}{l}\text { Column B: } \\
\text { Agreement }\end{array}$ \\
\hline Row I: I-thinking & Circumstances of politics & Political consensus \\
\hline Row II: We-thinking & Legal disagreement & Legal agreement \\
\hline
\end{tabular}

\footnotetext{
${ }^{34}$ Of course, the former involves an element of what might be called 'we-thinking': to think about justice is to think politically, which, as I argued in the previous section, presupposes a commitment to collective action. The distinction I am making here is between (i) determining one's own individual view about what should be done collectively and (ii) determining the collective view about what should be done collectively. We might say that the former is an exercise in 'applied political theory', while the latter an exercise in 'applied political political theory'.
} 


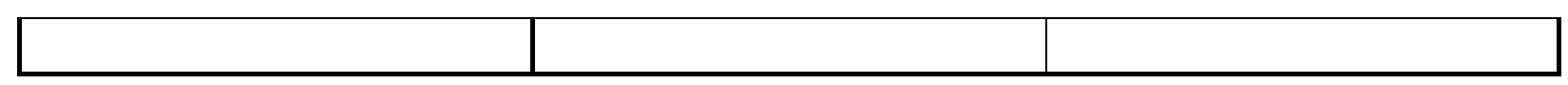

I do not mean to deny a connection between the adoption of a collective viewpoint and the resolution of disagreement. Resolving disagreement might well be the motive that people have for adopting a collective viewpoint, and under normal circumstances we might expect the range of legal disagreement to be narrower than the range of political disagreement. The point is just that law does not necessarily entail the resolution of disagreement. What it does entail is a distinctive register - a first-person-plural point-of-view - in which we might agree or disagree.

We can therefore see that it is not the resolution of disagreement that is really doing the work in Waldron's argument for the authority of law. After all, the obligation to respect the law applies regardless of whether the law is clear: in circumstances of legal disagreement, citizens and officials must nevertheless attempt in good faith to do as the law requires. The authority of law is not grounded in its practical capacity to co-ordinate action in the face of disagreement, but rather in the way in which it entails a shift from I-thinking to we-thinking - that is, the fact that law represents the common point of view of the political community.

This can be made clear by looking at the possibilities in Table 1. In the straightforward situation envisaged by Waldron, law moves us from a situation of political disagreement to legal agreement. Such a move, as Waldron points out, gives us a reason to respect the law. However, there are also cases in which we disagree about what the law is; since law's authority continues to hold in such cases, we can see that the value of respect for law does not rely on the resolution of disagreement. Finally, a shift from thinking about things on the basis of our individual political opinions to thinking about things from the collective viewpoint of the law can in fact give rise to disagreement where there was previously agreement. This can be seen from Riggs v Palmer, in 
which the Court of Appeals of New York was divided over the question of whether a grandson who had murdered his grandfather could inherit under the latter's will. ${ }^{35}$ The judges agreed that, were they to consider the matter on the basis of justice, they would conclude that the grandson ought not to inherit. They were thus in political consensus. Nevertheless, they disagreed about the law: adopting the collective viewpoint of the law moved them from political consensus to legal disagreement. ${ }^{36}$ But none of this suggests in any way that they were not, in making their decision, bound to attempt to ascertain the collective viewpoint of law rather than follow their individual political opinions. We can therefore see that the resolution of disagreement is not necessary for legal authority. The virtue of respect for law is engaged whenever we are called upon to follow the collective position of the political community, regardless of the existence of agreement or disagreement as to the demands of justice or the demands of law.

The emphasis that Waldron places on the resolution of co-ordination problems might give the misleading impression that his argument is an instrumental one, i.e. that law is authoritative because it allows us to avoid the conflict that would ensue if each individual attempted directly to secure justice as he or she saw fit. ${ }^{37}$ However, once we recognize that the obligation to respect the law holds even when we disagree about what the law requires, we can see that the real argument is essentially expressive in nature: adhering to the law even when one disagrees substantively with its content is a way of affirming one's commitment to the polity. While this claim is implicit in

\footnotetext{
${ }^{35}$ Riggs v. Palmer 115 N.Y. 506 (1889).

${ }^{36}$ Gray J, dissenting, said: '[I]f I believed that the decision of the question could be affected by considerations of an equitable nature, I should not hesitate to assent to views which commend themselves to the conscience. But the matter does not lie within the domain of conscience. We are bound by the rigid rules of law, which have been established by the legislature, and within the limits of which the determination of this question is confined.' (ibid., 515-6).

${ }^{37}$ At times Waldron explicitly suggests this, e.g. Waldron, "Kant's Legal Positivism," 1539; Waldron, Law and Disagreement, 103-5.
} 
Waldron's reasoning, it is muffled by his emphasis on the practical problems presented by political disagreement. If I am right in this, then we only understand the argument for the authority of law if we bear in mind that the CoP comprise not only the fact of disagreement, but also a shared commitment to a form of political togetherness which is robust across such disagreement.

\section{The Centrality of the Polity to Civility and Loyal Opposition}

We saw in the previous section that Waldron's focus on disagreement threatens to obscure the crucial point that accepting the authority of the law is a way of affirming one's commitment to the polity. Turning to Waldron's accounts of the principles of civility and loyal opposition, a similar pattern emerges. The goal of these principles is to recognize those who disagree with a regime's political decisions as nevertheless belonging to the political community; a narrow focus on the fact of disagreement might lead one to overlook this fact. Civility and loyal opposition help create and sustain an inclusive political community that is capable of being understood as the collective action of its members. Once more, the felt need for collective action is more fundamental than the fact of disagreement.

Civility, for Waldron, does not mean moderating one's views in the presence of others, but more basically remaining committed to political resolution of even the most deep-seated disagreements. ${ }^{38}$ This means being prepared to hear views that one feels profoundly wrong, distasteful even, and to respond without seeking to disengage. The essence of civility lies in not responding to one's political opponents with: 'I refuse to have anything to do with these people'. ${ }^{39}$

\footnotetext{
${ }^{38}$ Jeremy Waldron, "Civility and Formality," in Civility, Legality and Justice in America, ed. Austin Sarat (Cambridge: Cambridge University Press, 2014), 59.

${ }^{39}$ Ibid.
} 
The principle of loyal opposition goes further: it recognizes the presence of dissenting views not merely as legitimate, but as something to be actively embraced, worthy of an official constitutional role. ${ }^{40}$ Waldron praises the position of the Leader of the Opposition in the UK and other commonwealth constitutions for projecting the idea 'that criticism is $\mathrm{OK}$ and that policies are to be presented and defended in an explicitly and officially sanctioned adversarial environment' ${ }^{41}$ The principle of loyal opposition provides constitutional recognition of the fact that we welcome profound and passionate disagreement between citizens over political matters.

While there are instrumental reasons for civility and loyal opposition, the underlying motivation for these principles is expressive in nature: they rest upon the value of looking beyond one's personal views about justice to recognize one's political opponents as fellow members of the political community. Waldron makes the point in his discussion of civility:

If there is such a thing as civic friendship defined as an affirmative relation among those all of those - who inhabit the same polity, it has to be defined in a way that transcends affection, that transcends ideological hostility, and that transcends the differences that make us largely unintelligible to one another. ${ }^{42}$

Civility provides the mode of interaction appropriate for expressing such a relationship; it is (as its etymology suggests) the distinctive virtue governing interactions between citizens. By treating our political opponents civilly we recognize that - while we may think them naïve or callous or bigoted or perhaps just downright stupid - they are nevertheless fellow-citizens. Civility, then, is not simply about paying acknowledgment to disagreement, as if disagreement in itself were something

\footnotetext{
${ }^{40}$ Jeremy Waldron, "The Principle of Loyal Opposition", in Political Political Theory, chap 5.

${ }^{41}$ Ibid., 104.

${ }^{42}$ Waldron, "Civility and Formality," 57.
} 
worthy of respect. It is about recognizing something that we have in common notwithstanding our disagreements: we, fellow citizens, are all equal members of the political community. ${ }^{43}$

The idea of expressing political togetherness through the recognition of disagreement is also the rationale of loyal opposition - indeed, the phrase 'loyal opposition' perfectly encapsulates the apparently paradoxical nature of this idea. That we nowadays do not equate opposition with disloyalty is the result of the tectonic shifts in our understanding of politics that took place in the early modern period: our ability to see things in this way is a significant achievement. We should not be complacent here: history shows that the conceptual space between opposition and disloyalty is prone to collapse under pressure. ${ }^{44}$ Constitutionally embedding the principle of loyal opposition provides our fragile achievement with expressive nourishment and the ongoing success of the principle is an example of the potent symbolic force of constitutional structures.

As Waldron recognizes, the idea of 'loyal' opposition raises the question: 'loyal to what?' ${ }^{45} \mathrm{He}$ considers what he takes to be five unsuccessful attempts at an answer - loyalty to the Queen, the Constitution, 'constitutional essentials', 'the rules of the game' and the nation - before concluding that it is 'probably a mistake to distract ourselves' with the question. ${ }^{46}$ Instead he argues that "the word "loyal" in "loyal opposition"... indicates the way in which the opposition party must be regarded in a constitutional system... their loyalty is not to be questioned but is to be

\footnotetext{
${ }^{43}$ Cf Jeremy Waldron, “Citizenship and Dignity," in Understanding Human Dignity, ed. Christopher McCrudden (Oxford: Oxford University Press, 2013).

${ }^{44}$ For evidence of this, one needs to look no further than the current discourse surrounding Brexit in the UK, in which those opposed to leaving the European Union, and even those in favor of leaving but not without an ongoing trade deal, are regularly denounced by politicians and the right-wing press as 'traitors' (see Veronika Koller, "Traitors, Betrayal, Surrender: British politics now dripping with terms that fuel division," The Conversation (London), September 27, 2019).

${ }^{45}$ Waldron, "Loyal Opposition," 116-22.

${ }^{46}$ Ibid., 122.
} 
assumed' ${ }^{47}$ But while that might be a sound political precept, the question 'loyal to what?' nevertheless persists, at least as a philosophical puzzle.

Waldron ought to have identified the relevant locus of loyalty as the polity. This is a possibility he does not consider, or, if he does, he wrongly conflates with loyalty to the nation. He dismisses the suggestion that the nation could be the locus of loyalty by pointing out that 'opposition parties can be secessionist or anti-Unionist - as with Sinn Fein in Northern Ireland, Parti Québecois in Canada, or the Scottish National Party in the United Kingdom'. ${ }^{48}$ But while these parties are clearly not loyal to the nation in the sense of supporting the idea of a unified British/Canadian people, they have, in different ways and with varied degrees of enthusiasm, demonstrated acceptance of the legitimacy of the relevant polity.

Consider: the Bloc Québécois ${ }^{49}$ and the SNP have declined to use their presence in the Canadian and British legislatures to disrupt parliamentary business and have adopted principled policies on Canada/UK-wide issues.$^{50}$ Sinn Fein, by contrast, does not allow its candidates to take their seats in Westminster, but does participate in Northern Ireland (as well as Republic of Ireland) politics. Sinn Fein does not accept the legitimacy of the UK polity and so, so far as UK politics is concerned, is not a party of loyal opposition. The (admittedly faltering) success of the Good Friday

\footnotetext{
${ }^{47}$ Ibid. (emphasis in original).

${ }^{48}$ Ibid., 120-1.

49 Waldron's reference to the 'Parti Québecois in Canada' is misleading, as the Parti Québécois participates only at the Quebec state level. The Bloc Québécois is their sister party at the federal level.

${ }^{50}$ E.g., Alain Noël, "Distinct in the House of Commons: the Bloc Québécois as official opposition," in Canada: the state of the federation 1994, ed. Douglas M Brown and Janet Hiebert (Kingston: Institute of Intergovernmental Relations, 1994); Lori Young and Éric Bélanger, "BQ in the House: the nature of sovereigntist representation in the Canadian Parliament," Nationalism and Ethnic Politics 14, no. 4 (November 2008); Henry Mance, "SNP Morphs into Measured Opposition Force at Westminster," Financial Times (London), May 9, 2016.
} 
Agreement is down to its ability to construct a Northern Irish polity to which Sinn Fein as well as unionist parties can be loyal, albeit for different reasons. ${ }^{51}$

It should be clear here that 'loyalty to the polity' does not mean an open-ended commitment to maintaining the political community in its present form, but simply an acceptance of its current legitimacy and a commitment to engage with its politics. The Bloc Québécois and the SNP view Canada and the UK as polities that are each comprised of a union of nations, and while they favor secession from this union they do not question its political legitimacy. Sinn Fein, on the other hand, do not accept the legitimacy of the UK, but they accept Northern Ireland as a polity whose members collectively have the right to determine their own political future. ${ }^{52}$

The notion of the polity is therefore crucial for a proper grasp of Waldron's insights about civility and loyal opposition. Through engaging with political opponents civilly, individual citizens affirm that they accept their opponents as members of the political community. The principle of loyal opposition projects the same message institutionally. It is this link to the polity that distinguishes civility and loyal opposition from the simpler idea of mutual forbearance or 'live-and-let-live'. The latter is a purely private notion in which strangers agree to leave one another alone. Civility and loyal opposition, on the other hand, are 'distinctively political virtues' 53 that involve citizens recognizing one another as co-participants in a shared political practice.

\footnotetext{
${ }^{51}$ Strictly speaking, Sinn Fein are not an opposition party in Northern Ireland, as the consociational system in Stormont has ensured that they have been part of every government since the Good Friday Agreement was concluded in 1998.

52 The Good Friday Agreement provides that the parties (which includes Sinn Fein) 'recognize the legitimacy of whatever choice is freely exercised by a majority of the people of Northern Ireland with regard to its status'. Sinn Fein had previously maintained that the island of Ireland comprised a single irreducible polity, thus denying Northern Ireland any legitimate right to self-determination.

${ }^{53}$ See note 13 .
} 


\title{
V. Framing Collective Action: The Expressive Value of the Legislative
}

\begin{abstract}
Assembly
A significant portion of Waldron's oeuvre has been dedicated to articulating the 'dignity of legislation'. ${ }^{54}$ Despite his strong commitment to political equality, Waldron does not view legislation by representative assembly as a compromise to the practical unfeasibility of government by plebiscite, but believes that 'representation, rather than direct participatory choice, is the better democratic alternative'. ${ }^{55}$ Waldron's preference for representation is, I suggest, attributable to a recognition that democracy demands a decision-making process that not only affords fair weight to the views of each citizen (a consideration that on its own would seem to support majoritarianism), but which also can be understood as a form of joint action undertaken by all citizens. The legislative assembly performs what I called above the 'framing' role of the constitutional architecture: it embeds into political life a shared sense of politics as a process of collective self-government.
\end{abstract}

While the justification of majority-voting is based on the need to treat citizens fairly, the defense of legislation by assembly is grounded in a thesis about how politics can come to be understood as essentially a collective project. Waldron draws an analogy between legislation and the generation of customary law: in both cases law is generated not simply by the act of some

\footnotetext{
${ }^{54}$ See Waldron, The Dignity of Legislation; Waldron, Law and Disagreement, Part I; and Jeremy Waldron, "Representative Lawmaking," Boston University Law Review 89, no. 2 (April 2009) (reprinted, without substantive amendment, in Waldron, Political Political Theory, chap 6).

55 Waldron, "Representative Lawmaking," 346. However, contrast Jeremy Waldron, "The Core of the Case Against Judicial Review," Yale LJ 115, no. 6 (April 2006): 1388, in which he states that a legislative vote provides 'a reasonable approximation of the use of [majority-decision] as a decision-procedure among the citizenry as a whole'. I discuss this problematic argument below.
} 
authoritative will, but by pooling experience and judgment. Legislation and custom are thus based on an 'ascending' rather than a 'descending' theory of authority: ${ }^{56}$

In case of both statute and custom, the basis of legal authority has to do with a process (formal or informal) that brings together the plural and disparate experiences and opinions of those who are going to have to live with the norm in question. ${ }^{57}$

This process enables individuals to identify with statutes as 'their laws and the basis of the law's legitimacy [as] their understanding and their acceptance of the place the laws... occupy in their way of life' ${ }^{58}$ Thus the legislative process is possessed with an expressive value that is lacking from presidential/monarchical lawmaking and plebiscites (which, at least in modern nation-states, do not bring the people together for deliberation). Legislative processes are particularly suited to expressing a sense that the law is a kind of common property, rooted in an idea of the common good, rather than an imposition of dictates from on high. The point is not that this process will eventually give rise to a consensus, but that parties to ongoing disputes will see themselves as a community engaged in a joint project of self-government, rather than rival factions uneasily sharing the same piece of land. The legislative assembly plays a key role in structuring society's understanding of politics: it embodies the idea that, despite our differences of opinion, clashes of personal interest, etc., we remain united in our commitment to the project of governing ourselves collectively.

\section{A Lapse into Majoritarianism: The Core of the Case Against Judicial}

\section{Review}

\footnotetext{
${ }^{56}$ Waldron, Law and Disagreement, 55-6.

${ }^{57}$ Ibid., 66.

${ }^{58}$ Ibid., 66-7 (emphasis in original).
} 
In this section I highlight the perils of reducing issues of constitutional design to the question of how to deal fairly with disagreement. In his 'core case' article, ${ }^{59}$ Waldron takes a lopsided approach to the $\mathrm{CoP}$, focusing excessively on the fact of disagreement and consequently neglecting the need for political decisions to be understood as the outcome of collective action. This leads him to overlook the role of constitutional design in framing society's understanding of the political process, leaving us with a disappointingly thin line of reasoning - premised on a somewhat simplistic majoritarian conception of democracy - which fails to do justice to the insights that Waldron presents elsewhere.

Waldron presents the question of whether judicial review is anti-democratic as resting on the balance of 'outcome-related' and 'process-related' reasons. ${ }^{60}$ The outcome-related reasons include worries that legislatures might be swayed into violating rights by virtue of popular pressure and concerns that courts are prevented from engaging moral questions directly by their focus on constitutional texts and judicial precedents. ${ }^{61}$ Taken together, Waldron judges the outcome-related

${ }^{59}$ Waldron, "Core Case" (reprinted, without substantive amendment, in Waldron, Political Political Theory, chap 9). For an earlier formulation of this argument see Jeremy Waldron, "A Rights-Based Critique of Constitutional Rights," Oxford Journal of Legal Studies 13, no. 1 (Spring 1993).

${ }^{60}$ Ibid., 1372-6.

${ }^{61}$ Ibid., 1376-86. It might seem surprising to see Waldron considering such reasons, given his earlier opposition to rights-instrumentalism, and it is tempting to view this as a volte-face (see D. Enoch, "Taking Disagreement Seriously: On Jeremy Waldron's Law and Disagreement," Isr L Rev 39, no. 3 (Winter 2006): 25-6). But there is a crucial difference between Waldron's outcome-related reasons and the kind of rightsinstrumentalism that he rejected in Law and Disagreement: while the critique of rights-instrumentalism precludes us from designing a decision-making procedure that is likely to uphold a particular conception of rights (for instance a pro-choice over a pro-life stance on abortion), it does not prevent us from asking which procedures 'are most likely to get at the truth about rights, whatever that truth turns out to be' ("Core Case," 1373). 
reasons 'inconclusive'. ${ }^{62}$ The core case against judicial review therefore turns on Waldron's process-related argument.

Although Waldron does not use the phrase 'circumstances of politics' here, his processrelated argument depicts a scenario that is essentially a formulation of the CoP: a citizen (whom Waldron calls ' $\mathrm{C}_{\mathrm{n}}$ ') disagrees with a political decision and asks why she should nevertheless 'accept, comply, or put up with it' ${ }^{63} \mathrm{C}_{\mathrm{n}}$ asks two questions: (i) why was the decision left to be determined by this particular group of decision-makers? and (ii) why did this group use the particular decision-rule that they did ${ }^{64}$

Legislatures, Waldron argues, are able to provide reasonably convincing answers to these two questions. ${ }^{65}$ Firstly, their members were chosen by an election in which $\mathrm{C}_{\mathrm{n}}$ was able to participate on equal terms with her fellow citizens. Secondly, the use of majority-decision within the legislature provides: 'a reasonable approximation of the use of [majority-decision] as a decision-procedure among the citizenry as a whole'. ${ }^{66}$ Accordingly, the legislative process provides 'each person the greatest say possible compatible with an equal say for each of the others. $^{9} 67$

If, on the other hand, the decision has been made not by a legislature but by a court, then, Waldron says, there are no satisfactory answers to $\mathrm{C}_{\mathrm{n}}$ 's two questions. ${ }^{68}$ For the first question,

\footnotetext{
${ }^{62}$ Waldron, "Core Case," 1375.

${ }^{63}$ Ibid., 1387.

${ }^{64}$ Ibid.

${ }^{65}$ Ibid., 1387-9.

${ }^{66}$ Ibid., 1388.

${ }^{67}$ Ibid., 1388-9.

${ }^{68}$ Ibid., 1389-93.
} 
Waldron argues that there is no process-related justification for the make-up of the court's bench, because judges are not chosen by the electorate. For the second question, there is no moral basis for the court's adoption of majority-decision in order to resolve disagreement between the justices. Majority-decision 'is appropriate for persons who have a moral claim to insist on being regarded as equals in some decision-process, ${ }^{69}$ but there is no reason why this should be so among the judges. While legislatures can point to their representative role as the source of their claim to an equally-weighted vote, the use of majority-decision among judges appears arbitrary. He concludes that the process-related reasons support legislative decision-making and that this amounts to a strong case against judicial review, under normal circumstances. ${ }^{70}$

Now to say that the electoral and legislative processes provide a 'reasonable approximation' of a vote of the citizenry as a whole is to beg a rather obvious question: why should we be satisfied with an approximation? Why not hold a plebiscite? On Waldron's own argument it seems that this would have been more respectful to $C_{n}$, who may quite reasonably ask why her opinion should be given so little weight in comparison to the opinions of the legislators. We have already seen how Waldron would want to respond to this challenge: while a plebiscite succeeds in affording fair weight to the views of each individual, the process of legislation by a representative assembly is superior insofar as it can enable citizens to view political decisions as the outcomes of the collective action of the political community as a whole. ${ }^{71}$ However, the logic of the 'core case'

\footnotetext{
${ }^{69}$ Ibid., 1392.

${ }^{70}$ Waldron sets out these circumstances in a series of assumptions. The political community is presumed to have: (1) democratic institutions in reasonably good working order; (2) judicial institutions in reasonably good working order; (3) a commitment on the part of most members of society to the idea of individual and minority rights; and (4) persisting, substantial and good faith disagreement about rights (ibid., 1359-69).

${ }^{71}$ For the potential weaknesses of plebiscite in this regard, one need only look at the starkly polarizing effect that the UK referendum on membership of the EU has had on British politics; see Cathy Elliott, "All-
} 
argument does not leave any space for this response. The way in which the constitutional architecture frames a society's politics is neither an 'outcome-related' nor a 'process-related' consideration: it speaks to neither the substantive quality of decision-making nor the fairness with which the process treats individuals like $\mathrm{C}_{\mathrm{n}}$. In the 'core case' article Waldron, malgré lui, treats the constitutional structure as merely a 'machine which makes social decisions', ${ }^{72}$ thereby sidelining the issue of how legislative and judicial decision-making might differ in the way in which they cause disagreements to be framed.

The problem here lies in Waldron's attempt to answer a general question about the relative merits of two constitutional systems from the viewpoint of a particular citizen who disagrees with a particular decision. Putting the question into the mouth of $\mathrm{C}_{\mathrm{n}}$ presupposes that the decision in issue has already been politically framed and, more generally, that $C_{n}$ and her fellow citizens are able to identify themselves as members of a legitimate polity that decides questions like this through a process of collective action. ${ }^{73}$ Waldron thereby treats the framing of the issue in hand, and indeed the very make-up of the polity, as parameters that are independent of the question of constitutional design. And yet, as Waldron's defense of legislation itself shows, the constitutional architecture plays a crucial role in helping to define the nature of the political community, as well as affecting the framing of particular political questions. So in taking as his starting-point $\mathrm{C}_{\mathrm{n}}$ 's

out war? Brexit, voting and the production of division," Renewal: a journal of labour politics 25, no. 3 (July 2017).

${ }^{72}$ See note 29.

${ }^{73}$ Note that Waldron does not actually answer $C_{n}$ 's initial question. $C_{n}$ asks why she should 'accept, comply, or put up with' a decision with which she disagrees, not whether the decision has been reached by the most democratic procedure possible. Following Waldron's arguments about the authority of law, the appropriate response to $C_{n}$ is surely that she should accept the decision because it represents the community's collectively-decided position, regardless of whether that position has been determined by the legislature or by a court! 
objection to a particular decision, Waldron treats as fixed what are in fact dependent variables. This mistake leads him to overstate the significance of arithmetical political equality. By ignoring the question of how a constitutional system is able to promote the sense that all citizens are part of a collectively-acting political community, he is able to reduce the task of constitutional design to that of ensuring fair treatment of competing opinions. ${ }^{74}$

Once we recognize the framing role of the constitutional structure, we cannot focus solely on the way in which the legislature can integrate citizens into a cohesive political community, we must also consider whether judicial review might also possess similar value. Relevant arguments can be made either way. Perhaps legislative supremacy is superior because it reinforces a sense that the political community's most fundamental principles are to be determined in a forum which brings together members of all groups within that community. ${ }^{75}$ Perhaps judicial review is superior because institutionalising the principle that political decisions must be justifiable to each individual expresses respect for all citizens. ${ }^{76}$ No doubt many other arguments could be made. My point is that, by adopting a methodology that overlooks considerations about how constitutional systems frame our understanding of the nature of politics, Waldron effectively excludes these kinds of argument altogether.

These difficulties with Waldron's 'core case' show the risk of focusing on the fact of disagreement and failing to pay adequate attention to the need for decisions to be made through

\footnotetext{
${ }^{74} \mathrm{He}$ even goes so far as to say: 'The theory of such a process-based response is the theory of political legitimacy.' (Waldron, “Core Case," 1387).

75 As I argued in my PhD thesis: Alexander Latham, "Visions of Self-Government: constitutional symbolism and the question of judicial review" (PhD diss., University of Edinburgh, 2016).

${ }^{76}$ As has been argued, for example, by T. M. Scanlon, "Due Process," in Due Process, ed. J. Ronald Pennock and John W. Chapman (New York University Press 1977).
} 
collective action. Focusing narrowly on disagreement, we see the need to treat each individual's point-of-view equally, and are thus led to commend majoritarian decision-making procedures. We must remember, however, that we cannot build a polity solely on the basis of a fair treatment of conflicting opinions; there must be a shared commitment to resolve disagreements collectively. A constitution needs to promote and maintain a shared understanding between citizens that political decisions flow from their own collective action. To debate issues of constitutional design as if the only concern were to resolve disagreement fairly is to overlook the role that political institutions play in constituting the political community at such.

\section{Conclusion: The Circumstances of Politics and Politics (or, Political Political Theory and the Political)}

Waldron's presentation of the CoP as analogous to the circumstances of justice achieves its basic purpose of highlighting the fact that, to enable citizens to view themselves as members of a selfgoverning political community, we must put our substantive views about political morality to one side when thinking about constitutional questions and the duties we owe to one another as citizens. However, our study has revealed a significant disanalogy between Waldron's concept and its Humean forebear. While the circumstances of justice are facts that the philosopher of justice must simply accept, the CoP represents a condition which is worthy of being defended. In respecting the law and treating fellow citizens civilly, we express a commitment to the polity; similarly, the value of loyal opposition and legislation by assembly lies in their capacity to allow ideological

opponents to view themselves as nevertheless members of the same political community. Each of Waldron's arguments assumes that the political condition, in which conflicts can manifest themselves as disagreements over how to pursue a common interest, is worth preserving. 
We must thus understand the political condition as an achievement as well as a predicament - something that the 'circumstances of politics' label perhaps obscures. This comes to the fore when we encounter challenges that do not take the form of political disagreements, but are instead threats to the very idea of politics. I have in mind two very different kinds of challenge. One is motivated by a view that politics is merely a struggle between competing interest-holders intent on rent-seeking. Denying the value (and perhaps even the intelligibility) of collective action, neoliberalism promises a utopia in which market competition replaces political decision-making as the key force regulating society. ${ }^{77}$ The other challenge rejects the inherent contestability of politics. In place of the quintessentially political ideal of unity in diversity, populism seeks to establish a sense of collective action understood as the pursuit by a homogeneous people of a 'singular, unambiguous mandate' ${ }^{78}$ These challenges each threaten to undermine our capacity to have political disagreements: neoliberalism by presenting political convictions as mere cover for the pursuit of individual interests; populism by characterizing dissent as the work of outsiders, traitors, or a corrupt elite.

How politics can defend itself against the neoliberal Scylla and the populist Charybdis is a question beyond the scope of this article. However, attention to Waldron's use of the CoP reveals something that will be an important feature of any such response: the capacity of political virtues,

\footnotetext{
${ }^{77}$ See, for example, David Marquand, The Decline of the Public: the hollowing out of citizenship (Oxford: Polity, 2004); Wendy Brown, Undoing the Demos: neoliberalism's stealth revolution (Brooklyn: Zone Books, 2015); William Davies, "The Neoliberal State: power against 'politics"”, in The SAGE Handbook of Neoliberalism, ed. Damien Cahill, Melinda Cooper, Martijn Konings and David Primrose (Los Angeles: SAGE reference, 2018).

${ }^{78}$ Jan-Werner Müller, What is Populism? (Philadelphia: University of Pennsylvania Press, 2016), 77. See also William Galston, "The Populist Challenge to Liberal Democracy," Journal of Democracy 29, no. 2 (April 2018); Cas Mudde and Cristóbal Rovira Kaltwasser, Populism: a very short introduction (New York: Oxford University Press, 2017).
} 
practices and institutions to express commitment to the idea of politics as a form of valuable collective action that permits persisting disagreement. If the political sphere is to be protected, we must be attentive to its need for such symbolic nourishment. Our political institutions must both provide recognition of our disagreements and nurture the shared sense that in politics we are pursuing a common good through our collective action. 